\title{
DISTRIBUTION OF $\Delta^{5}-3 \beta$-HYDROXYSTEROID DEHYDROGENASE ACTIVITY IN THE GRAAFIAN FOLLICLE OF THE SHEEP
}

\author{
MARY F. HAY AND R. M. MOOR \\ Agricultural Research Council Unit of Reproductive Physiology and Biochemistry, \\ University of Cambridge*
}

(Received 2nd November 1974)

Summary. The localization of $\Delta^{5}-3 \beta$-hydroxysteroid dehydrogenase $(3 \beta$-HSD) has been examined in ovarian follicles in vivo and in vitro, and related to oestrogen and progesterone production.

In vivo, during the oestrous cycle, enzyme activity was restricted to the theca interna of the one or two most advanced follicles in each animal, but was present only between Days 2 and 5 and between Day 13 and ovulation. High levels of oestrogen were found in the ovarian venous blood only when follicles containing $3 \beta$-HSD were present. When sheep were injected with PMSG, the theca interna in a number of small follicles acquired $3 \beta$-HSD activity and began to secrete oestrogen within $12 \mathrm{hr}$ of the injection. The enzyme was not detected in the membrana granulosa of any follicles before ovulation but within a few hours of ovulation, $3 \beta$-HSD activity was present in the granulosa lutein cells.

In vitro, large activated follicles exhibited $3 \beta$-HSD activity in the theca interna and secreted high levels of oestrogen into the culture medium. When $\mathrm{LH}$ was added to the medium, oestrogen secretion was inhibited; within $48 \mathrm{hr}$, the follicles were secreting high levels of progesterone, and $3 \beta$-HSD activity was present in both the membrana granulosa and the theca interna. Dibutyryl cyclic adenosine monophosphate mimicked the effect of $\mathrm{LH}$ in suppressing oestrogen secretion, but did not induce production of progesterone; the distribution of $3 \beta$-HSD activity in follicles treated with this nucleotide was the same as in those cultured in control medium.

\section{INTRODUCTION}

Previous studies have shown that the development of ovarian follicles can be divided into two distinct phases. During the first, referred to as the period of activation, the theca interna acquires the capacity to secrete oestrogen and androgen. During the second, the follicle undergoes transformation, after which it no longer secretes oestrogen but produces principally progesterone, $20 \alpha-$ hydroxyprogesterone and pregnenolone; these three steroids are considered

\footnotetext{
* Postal address: Animal Research Station, 307 Huntingdon Road, Cambridge CB3 0JQ.
} 
to emanate from the membrana granulosa and are secreted only after luteinization has occurred (Seamark, Moor \& McIntosh, 1974). It has been postulated that $\mathrm{LH}$ has a twofold action in the process of transformation in that it inhibits oestrogen production (Moor, 1974), as well as stimulating progesterone secretion. It is probable that cyclic $3^{\prime}: 5^{\prime}$-AMP (cAMP) plays an essential rôle in mediating this action of LH on oestrogen secretion (McIntosh \& Moor, 1973).

In this investigation, the distribution of enzyme activity during the periods of activation of the theca interna and transformation of the membrana granulosa has been examined and related to the production of oestrogen and progesterone. For this purpose, we have used the enzyme $\Delta^{5}-3 \beta$-hydroxysteroid dehydrogenase ( $3 \beta$-HSD) which has a well-defined position in steroid biosynthesis (Samuels, Helmreich, Lasater \& Reich, 1951), and can be demonstrated histochemically (Wattenberg, 1958). This enzyme catalyses the conversion of pregnenolone to progesterone, and of dehydroepiandrosterone (DHA) to androstenedione.

Preliminary results of some of the experiments described in this paper have already been published as an abstract (Moor, Hay \& Caldwell, 1971).

\section{MATERIALS AND METHODS}

\section{Animals}

A total of seventy-one Welsh Mountain sheep was used in four experiments. The time of onset of oestrus, designated Day 0, was detected by means of a raddled vasectomized ram. All surgical procedures were carried out under anaesthesia induced with $30 \mathrm{mg}$ sodium pentobarbitone $/ \mathrm{kg}$, and maintained with fluothane and oxygen. Ovarian venous blood, when required for steroid analysis, was aspirated into a heparinized syringe.

\section{Experiments}

Experiment 1. Localization of $3 \beta-H S D$ activity in ovarian follicles during the oestrous cycle. Ovarian venous blood was collected, and the ovaries were immediately removed from thirty-three sheep at various times throughout the oestrous cycle (see Table 1). The largest follicle in each animal and usually all other follicles over $4 \mathrm{~mm}$ in diameter, together with a random selection of $2 \cdot 0-$ to $4 \cdot 0-\mathrm{mm}$ follicles, were frozen for histochemical study.

Experiment 2. Effect of injection of $P M S G$ on $3 \beta-H S D$ activity in ovarian follicles in vivo. On Day 13 of the cycle, seven sheep were treated with a single intravenous injection of 1200 i.u. PMSG (Folligon: Intervet Laboratories Ltd, Morden, Surrey). After 12, 24 or $48 \mathrm{hr}$, ovarian venous blood samples were collected and both ovaries were immediately removed. All follicles $5 \mathrm{~mm}$ or more in diameter, together with a random selection of 2- to 5-mm follicles were frozen for histochemical examination.

Experiment 3. Effect of LH on $3 \beta-H S D$ activity in the preovulatory follicle. In order to study more critically the effect of the high levels of LH circulating at oestrus on the distribution of $3 \beta$-HSD in the preovulatory follicle, it was desirable to have sheep in which the timing of the LH peak could be controlled. It has been 
found that a consistent pattern of hormonal changes occurs after removal of the CL on Day 5 of the cycle (Hay \& Moor, 1973). In such animals, LH levels remain low for $32 \mathrm{hr}$ after the operation.

The CL was removed on Day 5 from twelve sheep, and $1 \mathrm{mg}$ LH (NIH-LHS17) in saline was continuously infused from 18 to $24 \mathrm{hr}$ after the operation. The sheep were killed at 8-hr intervals from the end of the infusion until ovulation, which occurred about $24 \mathrm{hr}$ later; the ovaries were obtained for histochemical examination.

Experiment 4. Effect of LH and cAMP on the distribution of $3 \beta-H S D$ in follicles in vitro. Ovaries were removed aseptically on Day 13 or 14 of the cycle from nineteen sheep that had been injected intravenously with PMSG 18 to $24 \mathrm{hr}$ previously. Follicles with a diameter greater than $3 \mathrm{~mm}$, i.e. those that had responded to PMSG, were dissected and incubated individually as organ cultures, using similar techniques, media and culture conditions to those described previously (Moor, 1973). A total of ninety follicles was explanted. They were maintained in culture for $24 \mathrm{hr}$ before being allocated to one of three treatment groups. No hormone was added to the medium used for the follicles in the control group. For the second group of follicles, $\mathrm{LH}$ was added to the medium to give a final concentration of $5 \mu \mathrm{g}$ NIH-LH-S17/ml culture medium. For the third group of follicles, $\mathrm{N}^{6}-2^{\prime} 0$-dibutyryl cAMP (dbcAMP) (Boehringer) was added to the culture medium to give a final concentration of 0.2 to $1.0 \mathrm{~mm}$. The follicles were cultured for 2 to 7 days. The medium was changed daily and, after removal, was stored at $-20^{\circ} \mathrm{C}$ until required for steroid analysis. Follicles that had not secreted more than $40 \mathrm{ng}$ oestrogen/mg wet weight during the first $24 \mathrm{hr}$ in culture were eliminated from the study as they were considered not to have responded fully to the PMSG. The wet weight of the follicles was calculated from the diameter (Seamark et al., 1974) and the figure (40 ng oestrogen $/ \mathrm{mg}$ ) indicating full response to PMSG was established according to the criteria used previously (Moor, Hay, McIntosh \& Caldwell, 1973).

\section{Histochemistry}

Unfixed, freshly obtained follicles were embedded in O.C.T. Compound (Ames Co., Indiana, U.S.A.) and rapidly frozen with the aid of solid $\mathrm{CO}_{2}$. They could then be stored for up to 4 weeks at $-20^{\circ} \mathrm{C}$ before being examined for the distribution of $3 \beta$-HSD by the method described by Wattenberg (1958). The principal steroidal substrate used was dehydroepiandrosterone (DHA) dissolved in acetone; DHA in dimethyl formamide (DMF) and pregnenolone and $17 \alpha$-hydroxy-pregnenolone in both acetone and DMF were also tested as substrates. The reaction with DHA in DMF was similar to that with DHA in acetone; the other two steroids, regardless of solvent, gave a positive reaction in the same sites as DHA, but it was always weaker in intensity. For this reason, the observations described in this paper are those made when DHA in acetone was the substrate. The co-factor used was nicotinamide adenine dinucleotide (NAD: Boehringer).

The tests were done on 16- $\mu \mathrm{m}$ sections which were washed in cold acetone followed by cold phosphate buffer before being incubated at $37^{\circ} \mathrm{C}$ for 3 to $4 \mathrm{hr}$. Control sections were incubated in substrate-free medium. An additional 
section was used to demonstrate the presence of NAD-tetrazolium reductase (diaphorase). The experimental procedure was the same as that described by Hay \& Deane (1966) except that in the present study a phosphate-buffered saline (Dulbecco 'A': Oxoid Ltd, London) was used, and the sections were mounted in Gurr Hydramount (Searle Diagnostic, High Wycombe, Bucks.).

\section{Steroid analysis}

The levels of unconjugated oestrogen in samples of ovarian venous blood plasma and in the culture medium were measured by radioimmunoassay (Moor et al., 1973). The concentration of progesterone in the culture medium was determined by the method described by Seamark et al. (1974).

\section{RESULTS}

\section{Experiment 1}

The enzyme, $3 \beta$-HSD, was not found in the membrana granulosa in large follicles at any stage of the oestrous cycle, but it was present at certain stages (see Table 1) in the theca interna of the largest non-atretic follicle (PI. 1, Fig. 1). Small follicles often showed weak $3 \beta$-HSD activity in the theca interna at oestrus, but not at other stages of the cycle. The membrana granulosa of small follicles throughout the cycle occasionally gave a weak positive reaction, but often the control section of these follicles incubated without substrate was also positive.

Table 1 shows the relationship between the concentration of oestrogen in ovarian venous plasma and $3 \beta$-HSD activity in the ovarian follicles. There were two distinct periods in the cycle, namely between Days 3 and 5 and from Day 13 to oestrus, when one large follicle showed $3 \beta$-HSD activity (a 'positive' follicle). During these two periods, the level of oestrogen in the ovarian vein blood from the ovary with the positive follicle was high.

The intensity of the histochemical reaction in the theca interna of the large follicle increased progressively from Day 13 until oestrus. At oestrus, despite the continued presence of strong $3 \beta-\mathrm{HSD}$ activity in the theca interna of the

\section{EXPLANATION OF PLATE 1}

Unfixed frozen sections of sheep follicles incubated at $37^{\circ} \mathrm{C}$ for 3 to $4 \mathrm{hr}$ to show $\Delta^{5}-3 \beta$ hydroxysteroid dehydrogenase activity. $T=$ theca interna; $G=$ membrana granulosa. FIG. 1. Day 15 of normal cycle. Part of two neighbouring follicles. The upper one is a $3.5-\mathrm{mm}$ follicle in which the theca interna shows no enzyme activity. The lower one is the largest follicle (diameter $4.5 \mathrm{~mm}$ ) in which the theca interna is strongly positive. The membrana granulosa shows no enzyme activity in either follicle. $\times 160$.

Figs 2 and 3. Day 15 of the cycle, $48 \mathrm{hr}$ after injection of PMSG.

Frg. 2. Large follicle (diameter $6.3 \mathrm{~mm}$ ). The theca interna is strongly positive but there is no enzyme activity in the membrana granulosa (the dark dots in this layer are an artefact in the mounting medium). $\times 160$.

FIc. 3. Small follicle (diameter $3.5 \mathrm{~mm}$ ) which is representative of the second group of follicles to be stimulated; enzyme activity in the theca interna is weak. $\times 160$.

Fig. 4. Follicle cultured for 4 days in control medium. Moderate enzyme activity in theca interna, none in the membrana granulosa. $\times 130$.

Frg. 5. Follicle on Day 4 of culture, $72 \mathrm{hr}$ after addition of LH to the culture medium. Strong enzyme activity in both the theca interna and the membrana granulosa. $\times 130$. 
PLATE 1
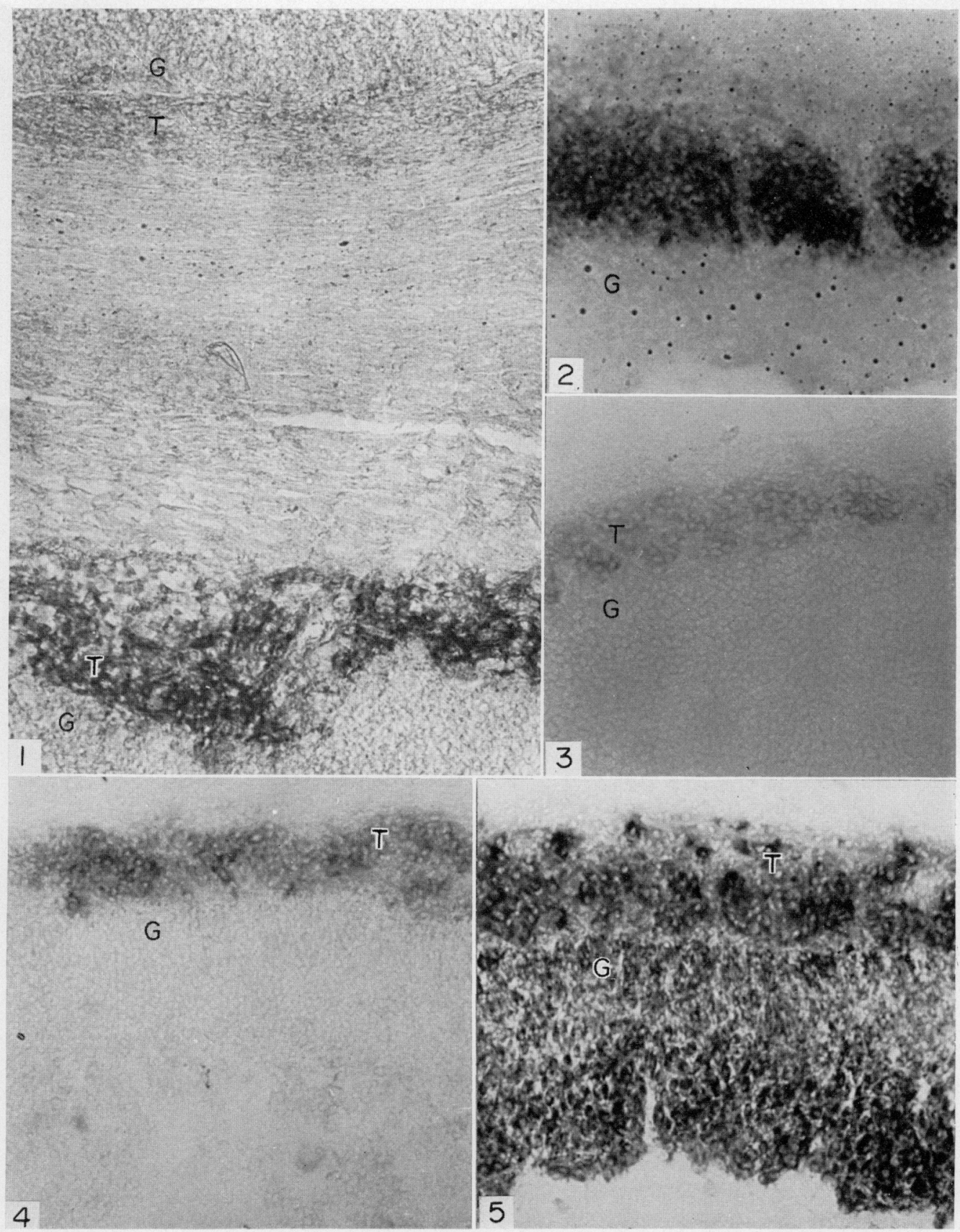

(Facing p. 316) 
Table 1. The concentration of oestrogen in ovarian venous plasma and intensity of $3 \beta$-hydroxysteroid dehydrogenase activity in the theca interna of Graafian follicles of untreated sheep during the oestrous cycle

\begin{tabular}{|c|c|c|c|c|c|}
\hline \multirow{2}{*}{$\begin{array}{l}\text { Stage of } \\
\text { cycle }\end{array}$} & \multirow{2}{*}{$\begin{array}{l}\text { Sheep } \\
\text { no. }\end{array}$} & \multicolumn{2}{|c|}{$\begin{array}{l}\text { Oestrogen conc. in ovarian } \\
\text { venous plasma }(\mathrm{pg} / \mathrm{ml})\end{array}$} & \multicolumn{2}{|c|}{$\begin{array}{c}\text { Activity of } 3 \beta \text {-hydroxysteroid dehydrogenase in } \\
\text { theca interna }\end{array}$} \\
\hline & & $\begin{array}{l}\text { Ovary with } \\
\text { largest follicle }\end{array}$ & Other ovary & $\begin{array}{l}\text { Largest } \\
\text { follicle }\end{array}$ & Other follicles \\
\hline Day 2 & $\begin{array}{l}1 \\
2 \\
3\end{array}$ & $\begin{array}{l}222 \\
245 \\
320\end{array}$ & $\begin{array}{l}217 \\
255 \\
-\end{array}$ & $\begin{array}{c}0 \\
0 \\
++\end{array}$ & $\begin{array}{l}0 \\
0 \\
-\end{array}$ \\
\hline Day 3 & $\begin{array}{l}4 \\
5 \\
6 \\
7\end{array}$ & $\begin{array}{r}-\overline{259} \\
294 \\
1028\end{array}$ & E & $\begin{array}{c}+ \\
+ \\
0 \\
++\end{array}$ & $\begin{array}{l}0 \\
0 \\
0 \\
\end{array}$ \\
\hline Day 4 & $\begin{array}{r}8 \\
9 \\
10\end{array}$ & $\begin{array}{r}1232 \\
238 \\
-\end{array}$ & $\bar{z}$ & $\begin{array}{l}+++ \\
++ \\
++\end{array}$ & $\begin{array}{l}\mathbf{0} \\
\mathbf{0} \\
\mathbf{0}\end{array}$ \\
\hline Day 5 & $\begin{array}{l}11 \\
12\end{array}$ & $\begin{array}{r}993 \\
1075\end{array}$ & $\begin{array}{l}243 \\
220\end{array}$ & $\begin{array}{c}++ \\
+\end{array}$ & $\begin{array}{l}0 \\
0\end{array}$ \\
\hline Day 8 & $\begin{array}{l}13 \\
14 \\
15 \\
16\end{array}$ & $\frac{305}{\overline{234}}$ & $\frac{223}{\overline{108}}$ & $\begin{array}{l}0 \\
\mathbf{T r} \\
0 \\
0\end{array}$ & $\begin{array}{l}0 \\
0 \\
0 \\
0\end{array}$ \\
\hline Day 11 & $\begin{array}{l}17 \\
18 \\
19 \\
20\end{array}$ & $\begin{array}{l}210 \\
249 \\
174 \\
239\end{array}$ & $\begin{array}{r}200 \\
265 \\
172 \\
72\end{array}$ & $\begin{array}{l}0 \\
0 \\
0 \\
0\end{array}$ & $\begin{array}{l}0 \\
0 \\
0 \\
0\end{array}$ \\
\hline Day 13 & $\begin{array}{l}21 \\
22 \\
23\end{array}$ & $\begin{array}{l}203 \\
423 \\
334\end{array}$ & $\begin{array}{l}230 \\
272 \\
183\end{array}$ & $\begin{array}{l}++ \\
+ \\
+\end{array}$ & $\begin{array}{l}\mathbf{0} \\
0 \\
0\end{array}$ \\
\hline Day 14 & $\begin{array}{l}24 \\
25 \\
26\end{array}$ & $\begin{array}{l}211 \\
445 \\
205\end{array}$ & $\begin{array}{l}259 \\
176 \\
195\end{array}$ & $\begin{array}{c}0 \text { (Atretic) } \\
++ \\
+\end{array}$ & $\begin{array}{c}\text { One 3-mm follicle, }++ \text {; others } 0 \\
0 \\
\text { One } 5 \text {-mm follicle, }+ \text {; others } 0\end{array}$ \\
\hline Day 15 & $\begin{array}{l}27 \\
28 \\
29 *\end{array}$ & $\begin{array}{l}1439 \\
1437 \\
2645\end{array}$ & $\begin{array}{l}262 \\
211 \\
221\end{array}$ & $\begin{array}{l}++ \\
+t \\
++\end{array}$ & $\begin{array}{l}0 \\
0 \\
0\end{array}$ \\
\hline Oestrus & $\begin{array}{l}30 \\
31 \\
32 \\
33\end{array}$ & $\begin{array}{l}182 \\
286 \\
276 \\
-\end{array}$ & $\begin{array}{l}180 \\
266 \\
245 \\
-\end{array}$ & $\begin{array}{c}++ \\
+++ \\
+++ \\
++\end{array}$ & $\begin{array}{l}\text { One follicle, Tr; others } 0 \\
\text { Several }+; \text { others } 0 \\
\text { Several }+; \text { others } 0\end{array}$ \\
\hline
\end{tabular}

The intensity of the $3 \beta$-hydroxysteroid dehydrogenase reaction was rated as follows: $0=$ no activity; $\operatorname{Tr}=$ trace;,,$++++++=$ increasing intensity of reaction; - , no data available.

* Ewe in which there were two equally large follicles in one ovary.

ovulating follicle, the oestrogen concentration in the ovarian vein blood fell to baseline levels.

\section{Experiment 2}

Under the influence of exogenous gonadotrophin, a number of small follicles acquired $3 \beta$-HSD activity, and there was a marked increase in the concentration of oestrogen in the ovarian venous blood (Table 2). Within $12 \mathrm{hr}$ of the injection of PMSG, there was an increase in the number of positive follicles in two of the three sheep examined, and the oestrogen levels in the ovarian venous blood of these animals had already begun to rise. Between 24 and $48 \mathrm{hr}$ after 


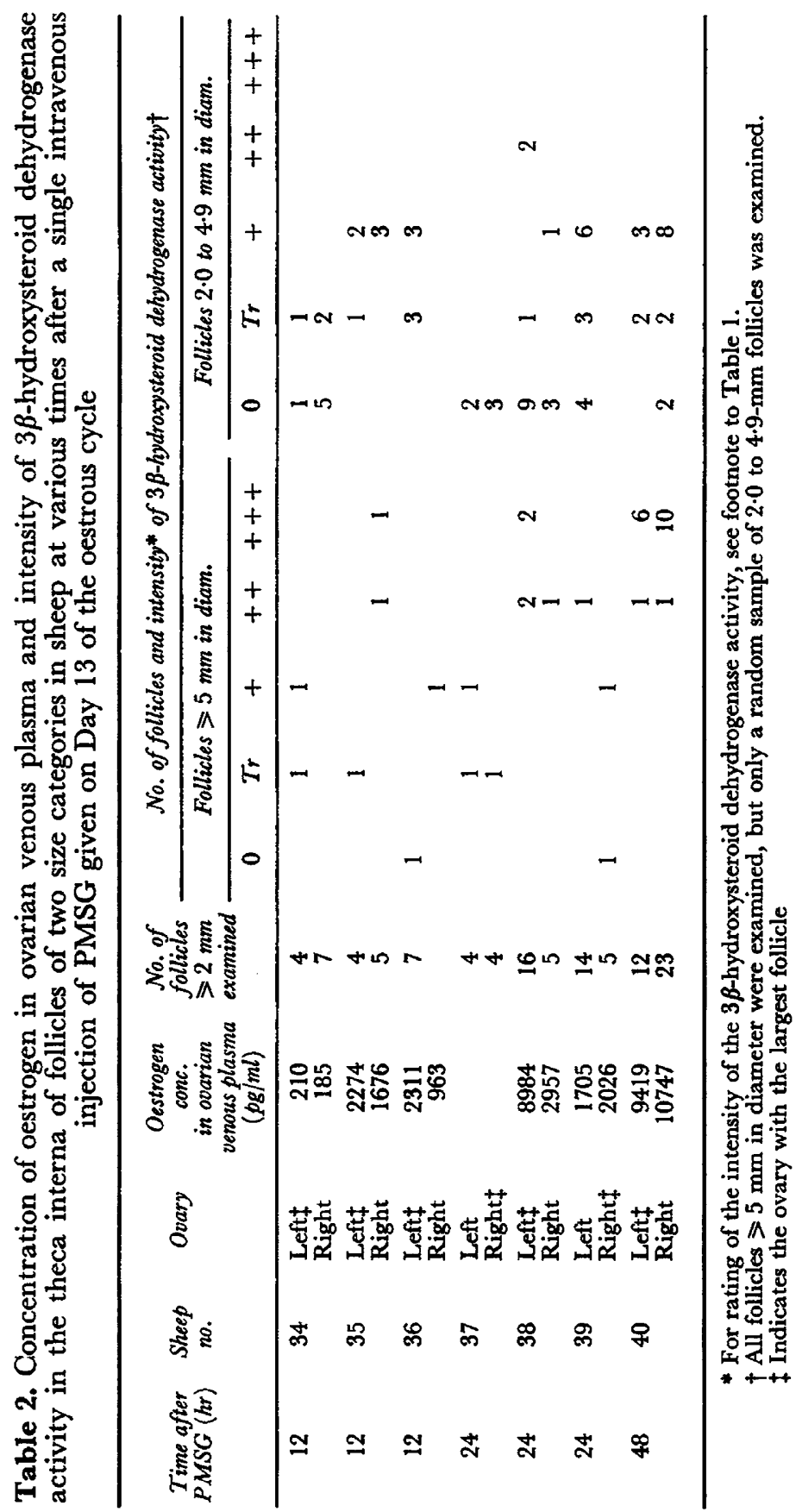


injection of the hormone, the number of follicles in each sheep with a diameter of $5 \mathrm{~mm}$ or more was greatly increased and all these follicles showed strong $3 \beta$-HSD activity in the theca interna but none in the granulosa (PI. 1, Fig. 2); there was also a group of smaller follicles that showed weak enzyme activity (PI. 1, Fig. 3).

\section{Experiment 3}

Infusion of LH into sheep from which the CL had been removed on Day 5 did not induce $3 \beta$-HSD activity in the membrana granulosa of any follicle before ovulation. The largest follicles (one or two in each animal), however, exhibited $3 \beta$-HSD activity in the theca interna.

In one of the sheep that was examined $24 \mathrm{hr}$ after the end of the infusion, the large follicle had recently ovulated. The granulosa lutein cells already showed $3 \beta$-HSD activity. Scattered round the edge of the newly formed CL were some strongly positive cells.

\section{Experiment 4}

Follicles grown in control medium secreted high levels of oestrogen (30 to $60 \mathrm{ng} / \mathrm{mg} / 24 \mathrm{hr}$ ) throughout the culture period (up to 7 days), but produced almost no progesterone $(<10 \mathrm{ng} / \mathrm{mg} / 24 \mathrm{hr}$ ). All the follicles exhibited strong $3 \beta$-HSD activity in the theca interna (Pl. 1, Fig. 4). Despite the very low levels of progesterone secreted by control follicles, weak enzyme activity was seen in the membrana granulosa of a few follicles on the 4th day in culture and in the majority by Day 5 ; by Day 7, enzyme activity was quite strong in the granulosa.

Addition of $\mathrm{LH}$ to the culture medium rapidly inhibited secretion of oestrogen and stimulated the production of progesterone. Within $24 \mathrm{hr}$ of addition of the gonadotrophin, significant amounts of progesterone were being secreted and maximal levels of production were reached on Day 3, that is $48 \mathrm{hr}$ after the commencement of $\mathrm{LH}$ treatment. The theca interna retained its enzyme activity throughout the culture period. The enzyme was not detectable in the granulosa cells $24 \mathrm{hr}$ after addition of $\mathrm{LH}$ to the medium despite the significant rise in the production of progesterone, but was clearly demonstrable in the basal part of the membrana granulosa by Day 3 and the whole of this layer was strongly positive by Day 4 (Pl. 1, Fig. 5).

When dbcAMP was added to the medium, oestrogen secretion was inhibited, but less rapidly than by LH; dbcAMP, however, failed to stimulate progesterone secretion. Histochemically, these follicles behaved in a similar manner to those cultured in control medium: $3 \beta$-HSD activity was present in the theca interna but was not seen in the membrana granulosa before Day 4 and it was still very weak in this layer in some follicles on Day 5.

\section{DISGUSSION}

The histochemical observations on both the number of follicles possessing $3 \beta$-HSD activity in vivo, and the stage of the cycle at which such follicles are present agrees well with recent biochemical observations on the steroidogenic capacity of individual follicles in sheep (Moor, 1973). It was found that only the largest one or two follicles secreted significant amounts of oestrogen in vitro; 
correspondingly, there were only one or two large follicles that exhibited $3 \beta$ HSD activity. The activity of this enzyme was restricted to the theca interna and was demonstrable only between Days 2 and 5, and after Day 13 of the cycle, the two periods at which the levels of oestrogen in the ovarian venous blood were elevated. In the follicle that was destined to ovulate, the intensity of the $3 \beta$-HSD reaction in the theca interna increased progressively from Day 13 to ovulation. The strongly positive cells that were scattered round the edge of the newly formed CL probably represent the remnants of the theca interna. There is no evidence in the sheep for secretion of progesterone by the preovulatory follicle (Bjersing \& co-authors, 1972), and this is reflected in the absence of $3 \beta$-HSD from the membrana granulosa. The limited distribution of enzyme activity outlined above could well explain the report of Rubin, Deane \& Hamilton (1963) that $3 \beta$-HSD could not be demonstrated histochemically in ovarian follicles of the sheep, cow or horse.

As in vivo, there was, in general, a good relationship between the localization of $3 \beta$-HSD activity and steroid production in cultured follicles. The enzyme was demonstrable in the theca interna of follicles secreting oestrogen, and it was present in both the theca and the membrana granulosa of follicles that were secreting progesterone, but some anomalies were observed in this relationship. Follicles cultured in control medium which contained no added LH did not secrete significant amounts of progesterone during the 7-day culture period, but $3 \beta$-HSD activity was demonstrable in the granulosa cells during the last 2 days in culture. In LH-treated follicles, on the other hand, secretion of progesterone started before $3 \beta$-HSD could be detected histochemically in the membrana granulosa. An unequivocal determination of the cellular components responsible for the early production of progesterone will be required before the validity of this last histochemical observation can be assessed. The retention of $3 \beta$-HSD activity by the theca interna in vivo and in vitro after the cessation of oestrogen secretion is not surprising since androgens and $17 \alpha$-hydroxylated progestins are still being produced by the theca at this time (Seamark et al., 1974).

The sheep resembles a number of other species (including rabbit, guinea-pig and cat) in which $3 \beta$-HSD activity in non-atretic follicles has been found only in the theca interna (see Baillie, Ferguson \& Hart, 1966), but differs from hamsters and women in whose follicles $3 \beta$-HSD activity is found in the membrana granulosa, as well as in the theca, immediately before ovulation; the presence of the enzyme in the granulosa has been associated with the preovulatory secretion of progesterone in these two species (Leavitt, Bosley \& Blaha, 1971; Friedrich, Breitenecker, Salzer \& Holzner, 1974). The sheep also differs from many other species (mouse, rat, guinea-pig, hamster, human) in which $3 \beta$-HSD activity is commonly found in the membrana granulosa of atretic follicles (see Baillie et al., 1966); the majority of atretic follicles in sheep show no $3 \beta$-HSD activity in the membrana granulosa, though in a few a positive reaction, which was possibly 'false', was obtained. Like the sheep, the mare has only one or two follicles in which $3 \beta$-HSD activity is histochemically demonstrable; this activity is, however, confined to the membrana granulosa and appears to be entirely absent from the theca (Hay, Allen \& Lewis, 1975). 
The group of follicles that shows weak $3 \beta$-HSD activity $12 \mathrm{hr}$ after the injection of PMSG almost certainly represents the follicle population which, in a previous study (Moor et al., 1973), was shown to be capable of secreting oestrogen in vitro when explanted $5 \mathrm{~min}$ to $12 \mathrm{hr}$ after injection of the gonadotrophin. It is noteworthy that $12 \mathrm{hr}$ after PMSG a large amount of oestrogen is secreted into the ovarian venous blood by follicles which show only weak histochemical activity (Table 2). These follicles enlarge markedly and become intensely reactive histochemically by $48 \mathrm{hr}$ (Pl. 1, Fig. 2). The small weakly stained follicles (Pl. 1, Fig. 3) present in the ovaries 24 to $48 \mathrm{hr}$ after PMSG injection probably represent the additional group of follicles that acquire the capacity to secrete oestrogen in vitro when exposed to PMSG in vivo for $24 \mathrm{hr}$ (Moor et al., 1973).

In the sheep, in vivo and in vitro, at least $24 \mathrm{hr}$ elapse before the membrana granulosa responds to the effects of LH by acquiring $3 \beta$-HSD activity. In the oestrous cycle, the first signs of activity of the enzyme in the granulosa lutein cells are not seen until a few hours after ovulation. When $\mathrm{LH}$ was infused into sheep from which the $\mathrm{CL}$ had been removed, there was no $3 \beta$-HSD activity in the granulosa up to $24 \mathrm{hr}$ after the infusion, but ovulation occurred shortly thereafter and enzyme activity developed in the newly formed CL.

Ovulation does not occur in vitro but nevertheless $3 \beta$-HSD activity becomes detectable in the granulosa cells 24 to $48 \mathrm{hr}$ after addition of $\mathrm{LH}$ to the culture medium. The independence of the acquisition of $3 \beta$-HSD activity by the membrana granulosa on the one hand and ovulation on the other is clearly demonstrated in vivo by the presence of the enzyme in luteinized follicles early in the cycle. Acquisition of enzyme activity by the membrana granulosa, however, may well be dependent on the occurrence of marked structural changes within this layer of cells. These changes, which include dissociation of individual granulosa cells and breakdown of the basal lamina, occur both in the normal cycle about $12 \mathrm{hr}$ after the preovulatory LH peak and in vitro within $24 \mathrm{hr}$ of the addition of $\mathrm{LH}$ to the culture medium (Moor, Hay \& Seamark, 1975).

\section{ACKNOWLEDGMENTS}

We wish to express our thanks to Professor T. R. R. Mann for reading this manuscript. We are grateful to the Hormone Distribution Programme of the National Institute of Arthritis, Metabolism and Digestive Diseases for the generous gift of $\mathrm{LH}$.

\section{REFERENCES}

Bailie, A. H., Ferguson, M. M. \& Hart, D. McK. (1966) Developments in Steroid Histochemistry, Ch. 5, pp. 72-102. Academic Press, London and New York.

Bjersing, L., Hay, M. F., Kann, G., Moor, R. M., Naftolin, F., Scaramuzzi, R. J., Short, R. V. \& YoungLAI, E. V. (1972) Changes in gonadotrophins, ovarian steroids and follicular morphology in sheep at oestrus. 7. Endocr. 52, 465-479.

Friedrich, F., Breitenecker, G., Salzer, H. \& Holzner, J. H. (1974) The progesterone content of the fluid and the activity of the steroid-3 $\beta$-ol-dehydrogenase within the wall of the ovarian follicles. Acta endocr., Copenh. 76, 343-352.

Hay, M. F., Allen, W. R. \& Lewis, I. M. (1975) Steroid biosynthesis in the Graafian follicle of the mare: histochemical distribution of $\Delta^{5}-3-\beta$-hydroxysteroid dehydrogenase. $\mathcal{F}$. Reprod. Fert., Suppl. 23 (in press). 
Hay, M. F. \& Deane, H. W. (1966) Attempts to demonstrate $3 \beta$ - and $17 \beta$-hydroxysteroid dehydrogenases histochemically in the testes of the stallion, boar, ram and bull. F. Reprod. Fert. 12, 551560.

HAy, M. F. \& MooR, R. M. (1973) The graafian follicle of the sheep: relationships between gonadotrophins, steroid production, morphology and oocyte maturation. Annls Biol. anim. Biochim. Biophys. 13, 241-248.

Leavitr, W. W., Bosley, C. G. \& Blaha, G. C. (1971) Source of ovarian preovulatory progesterone. Nature, New Biology, 234, 283-284.

McIntosh, J. E. A. \& Moor, R. M. (1973) Regulation of steroid secretion in sheep ovarian follicles. 7. Reprod. Fert. 35, 605-606.

Moor, R. M. (1973) Oestrogen production by individual follicles explanted from ovaries of sheep. 7. Reprod. Fert. 32, 545-548.

Moor, R. M. (1974) The ovarian follicle of the sheep: inhibition of oestrogen secretion by luteinizing hormone. F. Endocr. 61, 455-463.

Moor, R. M., Hay, M. F. \& CALDwell, B. V. (1971) The sheep follicle: relation between sites of steroid dehydrogenase activity, gonadotrophic stimulation and steroid production. F. Reprod. Fert. 27, 484-485.

Moor, R. M., Hay, M. F., Malntosh, J. E. A. \& Caldwel., B. V. (1973) Effect of gonadotrophins on the production of steroids by sheep ovarian follicles cultured in vitro. F. Endocr. 58, 599-611.

Moor, R. M., HaY, M. F. \& Stamark, R. F. (1975) The sheep ovary: regulation of steroidogenic, haemodynamic and structural changes in the large follicle and adjacent tissue before ovulation. 7. Reprod. Fert. (in press).

Rubin, B. L., Deane, H. W. \& Hamilton, J. A. (1963) Biochemical and histochemical studies on $\Delta^{5}-3 \beta$ hydroxysteroid dehydrogenase activity in the adrenal glands and ovaries of diverse mammals. Endocrinology, 73, 748-763.

Samuels, L., Helmreich, M., Lasater, M. \& Reich, H. (1951) An enzyme in endocrine tissues which oxidises $\Delta^{5}-3 \beta$-hydroxy steroids to $\alpha, \beta$ unsaturated ketones. Science, $\mathcal{N} . r .113,490-491$.

Seamark, R. F., Moor, R. M. \& MaIntosh, J. E. A. (1974) Steroid hormone production by sheep ovarian follicles cultured in vitro. 7. Reprod. Fert. 41, 143-158.

Wattenberg, L. W. (1958) Microscopic histochemical demonstration of steroid-3 $\beta$-ol dehydrogenase in tissue sections. 7. Histochem. Cytochem. 6, 225-232. 